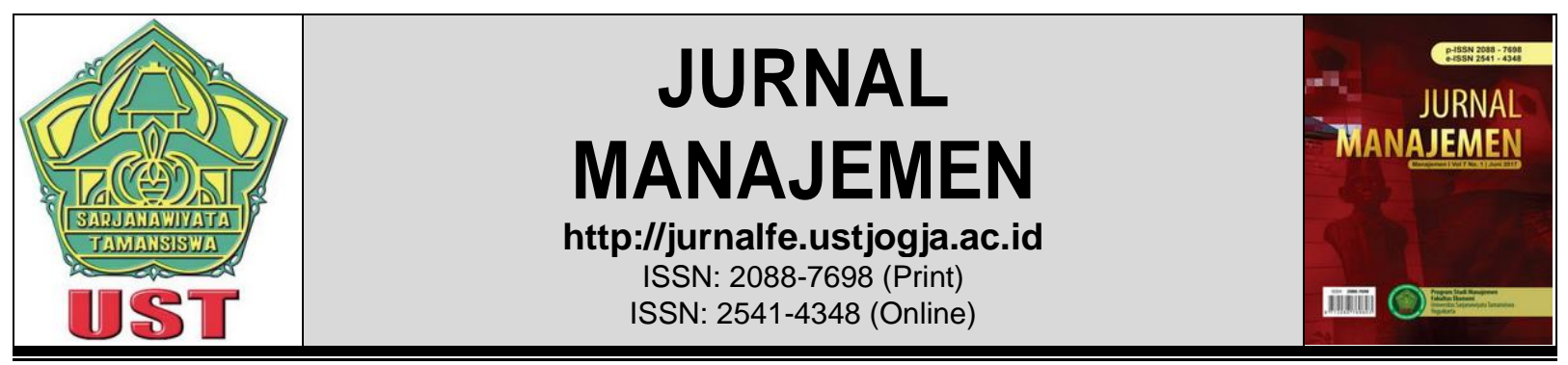

\title{
ANALISIS FAKTOR-FAKTOR BAURAN PEMASARAN (7P) YANG MEMPENGARUHI KEPUTUSAN PELAKU USAHA UMKM DALAM PEMILIHAN PENGAJUAN KREDIT PADA BANK DI DAERAH ISTIMEWA YOGYAKARTA
}

\author{
Ahsan Sumantika ${ }^{1}$ \\ Faizal Ardiyanto ${ }^{2}$ \\ ${ }^{1,2}$ Universitas PGRI Yogyakarta
}

Korespondensi: ahsansumantika@gmail.com

\begin{tabular}{ll}
\hline Informasi Naskah & \multicolumn{1}{c}{ Abstrak } \\
\hline Diterima: & This research aimed to test the influence offactors in marketing mix \\
7 Sept 2017 & which consist of product, price, place, promotion, people, physical \\
Revisi: & evidence, and process toward the loan selection decision by SME \\
1 November 2017 & businessmen in Yogyakarta Special Region bank. \\
Terbit: & The sampling method is purposive sampling with 99 respondents. \\
1 Desember 2017 & Multiple regression analysis is utilized to test the hypotheses. \\
\hline Kata Kunci: SME, 7P's & The testing result shows that there are 2 variables: product and \\
& physical evidence, significantly which is positively influence \\
& dependent variable. However, price, place, promotion, people, and \\
& process do not have significance influence towards dependent \\
& variable
\end{tabular}

\section{PENDAHULUAN}

Seiring dengan perkembangan zaman dan semakin banyaknya jumlah bank baik swasta ataupun milik pemerintah di Indonesia menyebabkan peningkatan intensitas persaingan antar bank. Bank-bank di Ind-onesia berlomba-lomba untuk berusaha memberikan pelayanan yang optimal bagi masyarakat guna memenangkan persaingan tersebut. Semakin banyak macam program atau produk berupa jasa ditawarkan kepada masyarakat pelaku usaha UMKM maka akan memudahkan pelaku usaha un-tuk memilih produk bank yang sesuai dengan kebutuhan. Salah satu produk bank yang dimaksud merupakan layanan perkreditan atau peminjaman dana kepada nasabah khususnya yang memiliki UMKM de-gan tujuan untuk mengembangkan usaha yang dimiliki.

Di Daerah Istimewa Yogyakarta (DIY) sendiri banyak sekali peluang-peluang bisnis yang menjanjikan. Meskipun demikian, tidak mudah untuk mendapatkan peluang bisnis tersebut karena UMKM terkendala masalah keuangan dan pembiayaan. Hal ini dapat diatasi dengan melakukan 
pinjaman kredit ke bank. Tetapi untuk melakukan pinjaman ke bank merupakan permasalahan yang tidak mudah. Kenyataanya banyak persyaratan pengajuan kredit yang harus dipenuhi oleh nasabah secara adminsitratif. Salah satu contoh persyaratan administrasi pengajuan kredit bagi UMKM adalah memberikan laporan atau informasi berupa data keuangan (catatan keuangan, catatan penjualan, catatan pembelian, neraca keuangan, laporan laba rugi, atau pembukuan lainnya). Untuk usaha kecil dan mikro hal ini merupakan masalah tersendiri karena umumnya mereka mencatat penjualan dan pembelian tidak terformat, lemah, dan tidak tertibnya pencatatan data keuangan karena dilakukan tidak secara formal. Sulitnya permasalahan akses pengajuan kredit di bank menyebabkan pelaku usaha kecil dan mikro terpaksa memilih jalan pintas dengan cara meminjam dana kepada rentenir meskipun bunga yang diberikan sangat tinggi dan memberatkan bagi peminjam.

Pemerintah tidak tinggal diam melihat kesulitan UMKM ini. Melalui kebijakan fiskal, pemerintah berupaya memberikan stimulus permodalan terhadap UMKM untuk menunjang kegiatan usahanya dengan program Kredit Usaha Rakyat (KUR) melalui beberapa bank. KUR adalah salah satu program pemerintah yang diharapkan dapat mengatasi masalah permodalan bagi UMKM. KUR adalah kredit/pembiayaan yang diberikan oleh perbankan kepada UMKM yang feasible tapi belum bankable. Maksudnya adalah usaha tersebut memiliki prospek bisnis yang baik dan memiliki kemampuan untuk mengembalikan (Kementerian Koordinator Bidang Perekonomian RI, 2017).

Faktor-faktor yang menjadi pertimbangan pelaku usaha UMKM dalam memilih pengajuan kredit di bank tercermin dalam bauran pemasaran (7P) sebagai berikut: (1) Produk (product) bank yang ditawarkan, produk yang dimaksud adalah produk jasa yang bersifat intangible berupa pinjaman bank, (2) harga (price) merupakan persepsi biaya yang dikeluarkan oleh pelaku usaha/nasabah UMKM untuk mendapatkan produk dari bank, (3) tempat (place) menunjukkan lokasi tempat bank berada, (4) promosi (promotion) penyampaian pesan bisnis dari bank kepada pelaku usaha/nasabah UMKM, (5) orang (people) sumber daya manusia yang terdapat dalam internal bank, (6) bukti fisik (physical evidence) merupakan kondisi fisik tempat pelayanan jasa dilaksanakan, (7) proses (process) menunjukkan metode bank memberikan pelayanan, dari input menjadi output.

\section{KAJIAN PUSTAKA DAN HIPOTESIS Pengambilan Keputusan}

Pengambilan keputusan didefiniskan sebagai rangkaian proses melalui alternatif-alternatif yang dapat dipilih dan dikel-ola untuk mencapai tujuan yang telah ditetapkan sebelumnya. Dalam hal ini, pengambil keputusan adalah pelaku usaha UMKM untuk menentukan pilihan pengajuan kredit di bank. Mereka harus menimbang dan menilai cost dan benefit yang akan timbul ketika mengajukan kredit di bank tertentu. Tentunya mereka akan memilih pilihan pengajuan kredit ke bank yang akan menawarkan benefit yang lebih besar daripada cost, dengan kata lain bank tersebut dapat menawarkan superior customer value. Menurut Drucker (1967) pengambilan keputusan yang efektif dihasilkan dari proses sistematis, dengan elemen-elemen yang jelas dapat diketahui, serta ditangani dalam rangkaian langkah-langkah jelas.

\section{Produk (product)}

Produk terbagi menjadi dua yaitu produk berupa barang untuk perusahaan yang bergerak dalam bidang manufaktur atau produksi dan produk berupa jasa untuk perusahaan yang bergerak dalam bidang jasa. Produk harus memberikan nilai kepada pe-langgan atau nasabah dan tidak 
harus berupa barang berwujud (Lin, 2011). Jadi produk berupa barang bersifat tidak berwujud, tidak dapat dipisahkan antara konsumsi dan produksi, dan tidak dapat disimpan. Beberapa produk yang ditawarkan bank diantaranya dapat berupa layanan penyimpanan, deposito, kredit, dan berbagai transaksi lainnya. Menurut Kotler dan Keller (2009) produk dapat terbagi ke dalam beberapa dimensi, diantaranya: product variety, quality, design, features, brand name, packaging, sizes, services, warranties, dan returns. Berdasarkan dimensi yang dijelaskan oleh Kotler dan Keller (2009) tersebut, peneliti mengambil beberapa dimensi yang terkait dengan perbankan yaitu: product variety, quality, features, dan service. Berdasarkan uraian tersebut maka dapat disimpulkan bahwa hipotesis penelititan adalah sebagai berikut:

H1: product berpengaruh signifikan dan positif terhadap keputusan pemilihan pengajuan kredit pada bank oleh pelaku usaha UMKM.

\section{Harga (price)}

Menurut sudut pandang nasabah, harga yang wajar suatu produk bank merupakan harga yang terjangkau. Harga ini harus sebanding dengan pelayanan yang ditawarkan oleh bank. Apabila terlalu mahal atau kurang terjangkau maka bank kurang mampu memberikan superior customer value karena penggunaan suatu jasa. Superior customer value dapat diraih apabila dalam persepsi nasabah, uang yang mereka berikan lebih sedikit dari benefit yang diberikan oleh bank atau nasabah merasa benefit yang diterima lebih besar. Selain itu, menurut Kirkup dan Rafiq (1999) harga melibatkan pengorbanan seorang pelanggan atau nasabah berupa waktu, biaya, dan usaha untuk mendapatkan pelayanan atau jasa dari penyedianya. Pengorbanan atau usaha tersebut diantaranya adalah biaya parkir, biaya perjalanan menuju bank, waktu menunggu ketika antri dalam bank, waktu menunggu ketika bank memproses transaksi, dan waktu ketika nasabah mengisi formulir untuk mendapatkan pelayanan tertentu yang ditawarkan oleh bank. Kotler dan Keller (2009) menjelaskan juga dimensi price diantaranya periode pembayaran dan termin kredit. Berdasarkan uraian tersebut maka dapat disimpulkan bahwa hipotesis penelititan adalah sebagai berikut:

H2: price berpengaruh signifikan dan positif terhadap keputusan pemilihan pengajuan kredit pada bank oleh pelaku usaha UMKM.

\section{Tempat (place)}

Menunjukkan lokasi tempat bank berada. Nasabah lebih cenderung menyukai lokasi yang dekat dengan tempat tinggal karena tidak memerlukan usaha dan biaya yang lebih untuk menuju ke bank. Menurut Lin (2011), place merupakan lokasi pemb-elian yang dilakukan pelanggan. Menurut Kotler dan Armstrong (2011) dalam Souar et al. (2015), place atau distribusi merupakan sekumpulan organisasi yang mendukung tersedianya produk yang digunakan untuk konsumsi. Dalam konteks jasa perbankan dapat disimpulkan bahwa place merupakan tempat nasabah mendapatkan layanan yang diberikan oleh bank. Peneliti mengadaptasi dimensi place berdasarkan Kotler dan Keller (2009) untuk perusahaan bidang jasa yaitu coverage, locations, dan transport. Berdasarkan uraian tersebut maka dapat disimpulkan bahwa hipotesis penelititan adalah sebagai berikut:

H3: place berpengaruh signifikan dan positif terhadap keputusan pemilihan pengajuan kredit pada bank oleh pelaku usaha UMKM.

\section{Promosi (promotion)}

Promosi merupakan berbagai macam cara perusahaan memberitahu pelanggannya tentang tawaran-tawaran yang diberikan (Lin, 2011). Promosi terdiri dari beberapa alat komunikasi yang 
memiliki tujuan utama menyampaikan pesan bank kepada nasabah dan berisi tentang informasiinformasi khusus. Oleh karena itu peneliti mengadaptasikan beberapa dimensi yang dijelaskan oleh Kotler dan Keller (2009), yaitu sales promotion, advertising, public relations dan direct marketing. Berdasarkan uraian tersebut maka dapat disimpulkan bahwa hipotesis penelititan adalah sebagai berikut:

H4: promotion berpengaruh signifikan dan positif terhadap keputusan pemilihan pengajuan kredit pada bank oleh pelaku usaha UMK-M.

\section{Orang (people)}

Kotler dan Keller (2009) menjelaskan bahwa people terdiri dari pemasaran internal dan karyawan yang terdapat dalam per-usahaan. Dalam hal ini, bank harus mema-ndang nasabah sebagai orang untuk memahami kehidupan mereka secara lebih mendalam, tidak hanya sebagai pembeli atau nasabah yang menggunakan jasanya. Demi mendapatkan manfaat yang optimal bagi nasabah dan bank maka pelayanan harus melibatkan kedua pihak tersebut secara langsung (Islam \& Rahman, 2015). Hal ters-ebut tidak terlepas dari sifat dasar produk berupa jasa yaitu penyedia jasa dan pelanggan tidak dapat terpisahkan ketika meng-gunakan jasa. Karyawan bank yang terlatih akan memberikan dampak positif terhadap nasabah. Interaksi dan sikap karyawan bank yang baik akan menimbulkan kepuasan nasabah terhadap bank tersebut. Berdasarkan uraian tersebut maka dapat disimpu-lkan bahwa hipotesis penelititan adalah sebagai berikut:

H5: people berpengaruh signifikan dan positif terhadap keputusan pemilihan pengajuan kredit pada bank oleh pelaku usaha UMKM.

\section{Bukti fisik (physical evidence)}

Bukti fisik dalam pemasaran jasa menunjukkan titik yang akan ditemui oleh nasabah ketika mereka akan melakukan transaksi jasa yang disediakan pada area pelayanan dalam bank. Pakaian yang dikenakan teller, satpam, customer service, dan bahkan kepala cabang suatu bank dapat mempengaruhi persepsi nasabah. Selain itu, Islam dan Rahman (2015) menjelaskan bahwa logo, tanda, simbol, lokasi, laporan tahunan, citra, dan brosur yang ditunjukkan oleh bank dapat mencerminkan kualitas jasa suatu bank. Islam dan Rahman (2015) menambahkan bahwa dekorasi, pencahay-aan, atmosfer, visual corporate, dan fasilitas juga termasuk faktor-faktor yang tergabung dalam bukti fisik suatu perusahaan, dalam hal ini bank. Sementara itu, menurut Lin (2011), physical evidence menunjukkan pengalaman dalam menggunakan produk atau jasa. Berdasarkan uraian tersebut maka dapat disimpulkan bahwa hipotesis penelititan adalah sebagai berikut:

H6: physical evidence berpengaruh signifikan dan positif terhadap keputusan pemilihan pengajuan kredit pada bank oleh pelaku usaha UMKM.

\section{Proses (process)}

Proses menunjukkan metode perusahaan dalam memberikan jasa sehingga penting bagi perusahaan untuk memiliki pengetahuan menyeluruh tentang manfaat pelayanan terhadap konsumen (Lin, 2011), dalam hal ini nasabah. Proses merefleksikan semua kreativitas, disiplin, dan struktur ke dalam manajemen pemasaran. Menurut Kotler dan Keller (2009) sekumpulan proses memandu perusahaan secara imajinatif menghasilkan panndangan dan terobosan produk, jasa, serta aktivitas-aktivitas pem-asaran. Sementara itu menurut Kirkup dan Rafiq (1999), process lebih ditekankan pada pentingnya pengelolaan jasa yang diberikan kepada pelanggan atau nasabah. Oleh karena itu, pengelolaan proses dalam bank merupakan hal yang penting dan tidak boleh 
diremehkan oleh penyedia jasa manapun. Berdasarkan uraian tersebut maka dapat disimpulkan bahwa hipotesis penelititan adalah sebagai berikut:

H7: process berpengaruh signifikan dan positif terhadap keputusan pemilihan pengajuan kredit pada bank oleh pelaku usaha UMKM.

\section{Bauran Pemasaran}

Marketing Mix atau yang disebut juga dengan bauran pemasaran diperkenalkan oleh Jerome McCarthy pada sekitar tahun 1960an (Rafiq \& Ahmed, 1995). McCarthy mengelompokkan menjadi empat faktor utama yaitu: product, price, place, dan promotion. Marketing mix diartikan sebagai alat-alat pemasaran yang digunakan perusahaan untuk mencapai tujuan-tujuan pemasaran dalam pasar target. Meskipun demikian, pada tahun 1980an terdapat tiga faktor tamba-han dalam marketing mix seperti yang dijelaskan oleh Booms dan Bitner (1981) dalam (Lin, 2011). Harlyani (2013) melakukan penelitian faktor-faktor bauran pem-asaran yang mempengaruhi keputusan nasabah mengajukan kredit usaha mikro dapat disimpulkan bahwa bauran pemasaran (7p) berpengaruh secara signifikan dan positif terhadap variabel dependen. Seme-ntara itu Hasan et al. (2016) juga melakukan penelitian tentang pengaruh marketing mix terhadap keputusan nasabah melakukan pinjaman berupa KPR di bank. Hasil penelitian menunjukkan bahwa product, place, promotion, people, physical evide-nce, dan process berpengaruh signifikan positif terhadap keputusan peminjaman KPR sementara untuk variabel price berpe-ngaruh signifikan negatif. Berdasarkan uraian tersebut maka dapat disimpulkan bahwa hipotesis penelititan adalah sebagai berikut:

Hs: Faktor-faktor bauran pemasaran ber-pengaruh secara bersama-sama terhadap keputusan pemilihan pengajuan kredit pada bank oleh pelaku usaha UMKM.

\section{METODE PENELITIAN}

Data utama yang digunakan adalah data primer yang didapatkan dari 99 sampel responden pelaku usaha UMKM di semua Kabupaten dan Kota Yogyakarta dengan menggunakan teknik purposive sampling pada bulan Juli - Agustus 2017. Teknik purposive sampling digunakan dengan tujuan untuk menyediakan data sesuai dengan pengalaman dan pengetahuan dari responden. Sebagian besar sampel tergolong dalam kategori usaha kecil dan mikro. berikut:

Keseluruhan variabel penelitian diu-kur dengan menggunakan Skala Likert lima poin sebagai

Tabel 1 Skala Likert

\begin{tabular}{ccc}
\hline No. & Keterangan & Skor \\
\hline 1. & Sangat Setuju (SS) & 5 \\
2. & Setuju (S) & 4 \\
3. & Kurang Setuju (KS) & 3 \\
4. & Tidak Setuju (TS) & 2 \\
5. & Sangat Tidak Setuju (STS) & 1 \\
\hline
\end{tabular}

Setiap item pertanyaan akan diberi nilai skor terendah yaitu 1 (satu) untuk keterangan jawaban sangat tidak setuju dan skor 5 (lima) untuk keterangan jawaban sangat setuju. 


\section{Variabel Penelitian}

Variabel-variabel yang digunakan dalam penelitian ini adalah sebagai berikut:

Tabel 2 Variabel Penelitian

\begin{tabular}{llc}
\hline No. & \multicolumn{1}{c}{ Nama Variabel } & Keterangan Variabel \\
\hline 1. & Keputusan Pemilihan Pengajuan Kredit UMKM $(\mathrm{Y})$ & Dependen \\
2. & Product $\left(\mathrm{X}_{1}\right)$ & Independen \\
3. & Price $\left(\mathrm{X}_{2}\right)$ & Independen \\
4. & Place $\left(\mathrm{X}_{3}\right)$ & Independen \\
5. & Promotion $\left(\mathrm{X}_{4}\right)$ & Independen \\
6. & People $\left(\mathrm{X}_{5}\right)$ & Independen \\
7. & Physical Evidence $\left(\mathrm{X}_{6}\right)$ & Independen \\
8. & Process $\left(\mathrm{X}_{7}\right)$ & Independen \\
\hline
\end{tabular}

\section{Model Penelitian}

Berikut ini adalah model yang digunakan dalam penelitiaan

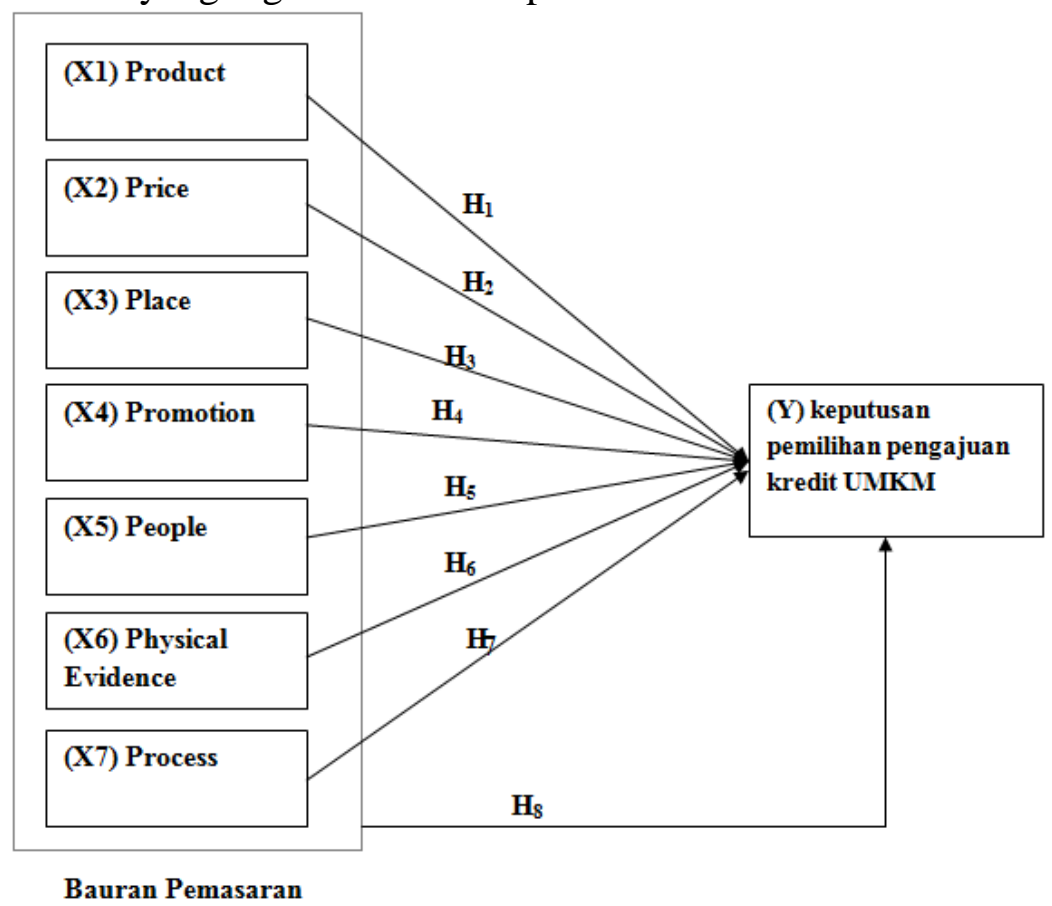

\section{Gambar 1 Model Penelitian}

\section{HASIL DAN PEMBAHASAN}

Sebelum dilakukan pengambilan data, peneliti melakukan uji instrumen yaitu uji validitas dan reliabilitas. Pengujian instru-ment dilakukan dengan pre-test terlebih dahulu. Pre-test dilakukan untuk menguji apakah kuesioner (instrumen) yang disusun sudah memenuhi asumsi validitas dan reliablitas. Jumlah responden yang d-igunakan dalam uji instrumen sebanyak 30 sampel. Uji validitas digunakan untuk me-nguji apakah instrumen yang dibangun da-pat mengukur apa yang 
seharusnya diukur. Sedangkan uji reliabilitas digunakan untuk mengukur sejauh mana hasil pengukuran tetap konsisten. Alat uji yang digunakan dalam uji validitas adalah analisis korelasi skor item pertanyaan dengan skor total. Sedangkan alat uji reliabilitas adalah cronbach alpha. Berikut ini adalah hasil uji validitas dan reliabilitas penelitian.

Tabel 3 Uji Validitas

\begin{tabular}{|c|c|c|c|c|}
\hline Variabel & Item & $R$ tabel & R hitung & Valid/Tidak \\
\hline \multirow[t]{5}{*}{ Product $\left(\mathbf{X}_{1}\right)$} & 1 & 0.724 & 0.361 & Valid \\
\hline & 2 & 0.815 & 0.361 & Valid \\
\hline & 3 & 0.826 & 0.361 & Valid \\
\hline & 4 & 0.764 & 0.361 & Valid \\
\hline & 5 & 0.819 & 0.361 & Valid \\
\hline \multirow[t]{4}{*}{ Price $\left(\mathbf{X}_{2}\right)$} & 1 & 0.785 & 0.361 & Valid \\
\hline & 2 & 0.878 & 0.361 & Valid \\
\hline & 3 & 0.921 & 0.361 & Valid \\
\hline & 4 & 0.596 & 0.361 & Valid \\
\hline \multirow[t]{3}{*}{ Place (X3) } & 1 & 0.855 & 0.361 & Valid \\
\hline & 2 & 0.889 & 0.361 & Valid \\
\hline & 3 & -0.117 & 0.361 & Tidak Valid \\
\hline \multirow[t]{3}{*}{ Promotion $\left(\mathbf{X}_{4}\right)$} & 1 & 0.922 & 0.361 & Valid \\
\hline & 2 & 0.884 & 0.361 & Valid \\
\hline & 3 & 0.784 & 0.361 & Valid \\
\hline \multirow[t]{4}{*}{ People (Xs) } & 1 & 0.807 & 0.361 & Valid \\
\hline & 2 & 0.923 & 0.361 & Valid \\
\hline & 3 & 0.927 & 0.361 & Valid \\
\hline & 4 & 0.826 & 0.361 & Valid \\
\hline Physical & 1 & 0.983 & 0.361 & Valid \\
\hline \multirow[t]{2}{*}{ Evidence ( $\left.\mathrm{X}_{6}\right)$} & 2 & 0.983 & 0.361 & Valid \\
\hline & 3 & 0.929 & 0.361 & Valid \\
\hline \multirow[t]{2}{*}{ Process $\left(\mathbf{X}_{7}\right)$} & 1 & 0.750 & 0.361 & Valid \\
\hline & 2 & 0.935 & 0.361 & Valid \\
\hline \multirow{4}{*}{$\begin{array}{l}\text { Keputusan } \\
\text { Pemilihan } \\
\text { Pengajuan } \\
\text { Kredit UMKM } \\
\text { (Y) }\end{array}$} & 1 & 0.891 & 0.361 & Valid \\
\hline & 2 & 0.914 & 0.361 & Valid \\
\hline & 3 & 0.912 & 0.361 & Valid \\
\hline & 4 & 0.212 & 0.361 & Tidak Valid \\
\hline
\end{tabular}

Berdasarkan tabel 3 terdapat item pertanyaan yang dinyatakan tidak valid yakni item pertanyaan variabel place $\left(\mathrm{X}_{3}\right)$ item pertanyaan nomor 3 dan variabel keputusan pemilihan pengajuan kredit UMKM (Y) item pertanyaan nomor 4. Oleh karena itu, item yang tidak valid tidak digunakan dalam pengujian hipotesis.

Berikut ini adalah hasil dari uji reliabilitas untuk masing-masing variabel 
Tabel 4 Uji Reliabilitas

\begin{tabular}{lccc}
\hline \multicolumn{1}{c}{ Variabel } & $\begin{array}{c}\text { Jumlah } \\
\text { Item }\end{array}$ & $\begin{array}{c}\text { Cronbach's } \\
\text { Alpha }\end{array}$ & Keterangan \\
\hline Product (X1) & 5 & 0.848 & Reliabel \\
Price (X2) & 4 & 0.814 & Reliabel \\
Place (X3) & 3 & 0.683 & Reliabel \\
Promotion (X4) & 3 & 0.810 & Reliabel \\
People (X5) & 4 & 0.893 & Reliabel \\
Physical Evidence (X6) & 3 & 0.963 & Reliabel \\
Process (X7) & 2 & 0.559 & Cukup \\
Keputusan Pemilihan Pengajuan & 4 & 0.869 & Reliabel \\
Kredit UMKM (Y) & & &
\end{tabular}

Berdasarkan tabel 4 di atas setiap variabel mempunyai nilai cronbach alpha lebih dari 0.6 maka dikatakan reliabel. Pengecualian terjadi pada variabel X7 (process). Nilai reliabilitas X7 sebesar 0.559 masih menunjukkan reliabilitas yang cukup baik dan mendekati 0.6.

\section{Data Demografi Responden}

Berikut ini data demografi responden yang digunakan dalam penelitian

Tabel 5 Usia Responden

\begin{tabular}{lcc}
\hline Usia (Tahun) & Frekuensi & Persentase (\%) \\
\hline $20-30$ & 6 & $6.06 \%$ \\
$31-40$ & 35 & $35.35 \%$ \\
$41-50$ & 40 & $40.40 \%$ \\
$51-60$ & 16 & $16.16 \%$ \\
$61-70$ & 1 & $1.01 \%$ \\
N/A & 1 & $1.01 \%$ \\
\hline Total & 99 & $100 \%$ \\
\hline
\end{tabular}

Tabel 6 Jenis Kelamin Responden

\begin{tabular}{lcc}
\hline Jenis Kelamin & Frekuensi & Persentase (\%) \\
\hline Laki-laki & 53 & 53.5 \\
Perempuan & 46 & 46.5 \\
\hline Total & 99 & 100 \\
\hline
\end{tabular}

Tabel 7 Jenis Usaha Responden

\begin{tabular}{lcc}
\hline \multicolumn{1}{c}{ Jenis Usaha } & Frekuensi & $\begin{array}{c}\text { Persentase } \\
(\mathbf{\%})\end{array}$ \\
\hline Angkringan & 10 & 10.1 \\
Apotek & 1 & 1 \\
Bengkel kendaraan & 5 & 5.1 \\
Kaos sablon & 1 & 1 \\
Katering & 2 & 2
\end{tabular}




\begin{tabular}{lcc}
\hline \multicolumn{1}{c}{ Jenis Usaha } & Frekuensi & $\begin{array}{c}\text { Persentase } \\
(\boldsymbol{\%})\end{array}$ \\
\hline Kedai kopi & 1 & 1 \\
Konter hp/pulsa & 7 & 7.1 \\
Laundry & 1 & 1 \\
Pedagang & 8 & 8.1 \\
Penjahit & 1 & 1 \\
Pet shop & 3 & 3 \\
Peternak bebek & 1 & 1 \\
Rental motor & 1 & 1 \\
Salon & 4 & 4 \\
Tambal ban & 1 & 1 \\
Toko & 20 & 20.2 \\
Usaha foto copy & 1 & 1 \\
Usaha tempe/tahu & 3 & 3 \\
Warung makan & 28 & 28.3 \\
\hline Total & 99 & 100 \\
\hline
\end{tabular}

Tabel 8 Data Kabupaten Asal

\begin{tabular}{lcc}
\hline \multicolumn{1}{c}{ Kabupaten } & Frekuensi & Persentase (\%) \\
\hline Sleman & 11 & 11,1 \\
Yogyakarta & 13 & 19,2 \\
Bantul & 53 & 53,5 \\
Kulon Progo & 7 & 7,1 \\
Gunung Kidul & 9 & 9,1 \\
\hline \multicolumn{1}{c}{ Total } & 99 & 100 \\
\hline
\end{tabular}

Secara lengkap persamaan regresi berganda dapat ditulis sebagai berikut :

$$
Y=a+b_{1} X_{1}+b_{2} X_{2}+b_{3} X_{3}+b_{4} X_{4}+b_{5} X_{5}+b_{6} X_{6}+b_{7} X_{7}+\varepsilon
$$

Berikut ini adalah tabel hasil pengujian hipotesis:

Tabel 9 Uji Simultan (F)

\begin{tabular}{llllll}
\hline & $\begin{array}{l}\text { Sum of } \\
\text { Squares }\end{array}$ & Df & $\begin{array}{l}\text { Mean } \\
\text { Square }\end{array}$ & F & Sig \\
\hline Regression & 6.591 & 7 & 0.942 & 7.910 & $0.000^{\mathrm{a}}$ \\
Residual & 10.831 & 91 & 0.119 & & \\
Total & 17.422 & 98 & & & \\
\hline
\end{tabular}


Tabel 10 Hasil Analisis Regresi Berganda

\begin{tabular}{llllll}
\hline & Coefficients & t Stat & Sig. & $R^{2}$ & Adj. $R^{2}$ \\
\hline Intercept & -0.912 & -1.059 & 0.293 & 0.378 & 0.330 \\
Product $\left(\mathrm{X}_{1}\right)$ & 0.568 & 3.610 & 0.001 & & \\
Price $\left(\mathrm{X}_{2}\right)$ & -0.057 & -0.747 & 0.457 & & \\
Place $\left(\mathrm{X}_{3}\right)$ & 0.247 & 1.604 & 0.112 & & \\
Promotion $\left(\mathrm{X}_{4}\right)$ & 0.064 & 0.768 & 0.444 & & \\
People $\left(\mathrm{X}_{5}\right)$ & 0.001 & 0.012 & 0.990 & & \\
Physical Evidence $\left(\mathrm{X}_{6}\right)$ & 0.344 & 3.624 & 0.000 & & \\
Process $\left(\mathrm{X}_{7}\right)$ & 0.108 & 1.023 & 0.309 & & \\
\hline
\end{tabular}

Persamaan Regresi :

$\mathrm{Y}=-0.912+0.568 \mathrm{X}_{1}-0.057 \mathrm{X}_{2}+0.247 \mathrm{X}_{3}+0.064 \mathrm{X}_{4}+0.001 \mathrm{X}_{5}+0.344 \mathrm{X}_{6}+0.108 \mathrm{X}_{7}$

Keterangan :

$\begin{array}{lll}\mathrm{Y} & : \text { Keputusan pemilihan pengajuan kredit oleh UMKM } \\ \mathrm{a} & : \text { Konstanta } \\ \mathrm{X}_{1} & : \text { Koefisien regresi product } \\ \mathrm{X}_{2} & : \text { Koefisien regresi price } \\ \mathrm{X}_{3} & : \text { Koefisien regresi place } \\ \mathrm{X}_{4} & : \text { Koefisien regresi promotion } \\ \mathrm{X}_{5} & : \text { Koefisien regresi people } \\ \mathrm{X}_{6} & : \text { Koefisien regresi physical evidence } \\ \mathrm{X}_{7} & : \text { Koefisien regresi process } \\ \varepsilon & : \text { Tingkat kesalahan (error) }\end{array}$

Berdasarkan hasil pengujian hipotesis tabel di atas maka dapat disimpulkan beberapa hal berikut ini:

1. Hasil uji analisis regresi berganda menunjukkan bahwa variabel product $(\mathrm{X}-1)$ berpengaruh secara signifikan dan postif terhadap variabel keputusan pemilihan pengajuan kredit oleh UMKM karena memiliki nilai signifikansi $0.001<\alpha(0.05)$ sehingga hipotesis $\mathrm{H}_{1}$ didukung.

2. Untuk variabel price $\left(\mathrm{X}_{2}\right)$ memiliki nilai signifikansi $0.457>\alpha(0.05)$ hal ini menunjukkan bahwa variabel price tidak berpengaruh secara signifikan terhadap variabel keputusan pemilihan pengajuan kredit oleh UMKM, sehingga hipotesis $\mathrm{H}_{2}$ tidak didukung.

3. Variabel place $\left(\mathrm{X}_{3}\right)$ memiliki nilai signifikansi $0.112>\alpha(0.05)$ hal ini menunjukkan bahwa variabel place tidak berpengaruh secara signifikan terhadap variabel keputusan pemilihan penga-juan kredit oleh UMKM, sehingga hip-otesis $\mathrm{H}_{3}$ tidak didukung.

4. Variabel promotion $\left(\mathrm{X}_{4}\right)$ memiliki nilai signifikansi $0.444>\alpha(0.05)$ hal ini menunjukkan bahwa variabel promoti-on tidak berpengaruh secara signifikan terhadap variabel keputusan pemilihan pengajuan kredit oleh UMKM, oleh karena itu hipotesis H4 tidak didukung.

5. Variabel people $\left(\mathrm{X}_{5}\right)$ memiliki nilai signifikansi $0.990>\alpha(0.05)$ hal ini menunjukkan bahwa people tidak berpe-ngaruh secara signifikan terhadap var-iabel keputusan pemilihan pengajuan kredit oleh UMKM, oleh karena itu hipotesis $\mathrm{H}_{5}$ tidak didukung. 
6. Variabel physical evidence $\left(\mathrm{X}_{6}\right)$ mem-iliki nilai signifikansi sebesar $0.000<\alpha(0.05)$ hal ini menunjukkan bahwa physical evidence berpengaruh secara signifikan dan positif terhadap variabel keputusan pemilihan pengajuan kredit oleh UMKM, oleh karena itu hipotesis $\mathrm{H}_{6}$ didukung.

7. Variabel process $\left(\mathrm{X}_{7}\right)$ memiliki nilai signifikansi $0.309>\alpha(0.05)$ hal ini menunjukkan bahwa process tidak berpengaruh secara signifikan terhadap variabel keputusan pemilihan pengajuan kredit oleh UMKM, oleh karena itu hipotesis $\mathrm{H}_{8}$ tidak didukung.

8. Berdasarkan hasil uji $\mathrm{F}$ atau uji simultan di atas dapat dibuktikan bahwa faktor-faktor bauran pemasaran berpengar-uh secara simultan terhadap keputusan pe-milihan pengajuan kredit pada bank oleh pelaku usaha UMKM.dengan nilai signifikansi $0.000<\alpha(0.05)$ sehingga hipotesis $\mathrm{H}_{8}$ didukung.

9. Nilai Adjusted $R^{2}$ sebesar 0.330 men-unjukkan bahwa variasi variabel-variabel independen dapat menjelaskan variasi variabel dependen adalah sebesar $33 \%$ sementara sisanya sebesar $67 \%$ dijelaskan oleh variabel-variabel lain di luar penelitian.

\section{PENUTUP}

Berdasarkan hasil pengujian hipotesis tersebut maka peneliti dapat menyimpulan bahwa terdapat dua faktor dalam bauran pemasaran yang berpengaruh secara signifikan terhadap keputusan pemilihan pengajuan kredit di bank oleh para pelaku UMKM yaitu product $\left(\mathrm{X}_{1}\right)$ dan physical evide-nce $\left(\mathrm{X}_{6}\right)$ hal ini didukung oleh penelitian Hasan et al. (2016) dan Harlyani (2013). Untuk faktor-faktor bauran pemasaran lain seperti price, place, promotion, people, dan process yang tidak signifikan, berbeda dengan hasil penelitian Hasan et al. (2016) dan Harlyani (2013). Sementara itu, berdasarkan hasil uji simultan dapat dibuktikan bahwa faktor-faktor bauran pemasaran berpengaruh secara bersama-sama terhadap kepu-tusan pemilihan pengajuan kredit pada bank oleh pelaku usaha UMKM.

\section{REFERENSI}

Bitner, M. J., \& Booms, B. H.1981. Mark-eting Strategies and Organization Structure for Service Firms. Mar-keting of Services, 47-52.

Drucker, P. F. 1967. The Effective Decis-ion. Harvard Business Review Web Site: https://hbr.org/1967/01/the-effective-decision

Harlyani, H. 2013. Keputusan Nasabah Mengajukan Kredit Usaha Mikro, Faktor-faktor Bauran Pemasaran yang Mempengaruhi Keputusan Nasabah Mengajukan Kredit Usaha Mikro pada Sahabat UKM-SMF Cabang Samarinda. Jurnal Administrasi Bisnis, 1(1), 8-16.

Hasan, S., Wahid, M., \& Basalamah, M. S. 2016. Marketing Mix Effect on the Decision of Customers in The Matter In Choosing The Home Purchase Loans In PT. BNI 46 Griya BNI (Persero) Tbk. Branch Makassar. International Journal of Business and Management Invention, 5(6), 20-30.

Islam, M. F., \& Rahman, M. M. 2015. Service Marketing Mix and Their Impact on Bank Marketing Performance: A Case Study On Janata Bank Limited, Bangladesh. Journal for Worldwide Holistic Sustainable Development, 1(1), 16-32.

Kementerian Koordinator Bidang Pere-konomian RI. 2017. Kredit Usa-ha Rakyat. Website Kementerian Koordinator Bidang Perekonomian RI: www.kur.ekon.go.id 
Kirkup, M. H., \& Rafiq, M. 1999. Mar-keting Shopping Centres: Challe-nges in the UK Context. Journal of Marketing Practice: Applied Mar-keting Science, 5(5), 119-133.

Kotler, P. 2011. Marketing Management, Millenium Edition.

Kotler, P., \& Keller, K. L. 2009. Market-ing Management (Vol. 22).

Lin, S. M. 2011. Marketing Mix (7P) and Performance Assessment of West-ern Fast Food Industry in Taiwan: An Application by Associating DEMATEL and ANP. African Journal of Business Management, 5(26), 10634-10644.

Rafiq, M., \& Ahmed, P. K. 1995. Using the 7Ps As A Generic Marketing Mix. Marketing Intelligence \& Planning, 13(9), 4-15.

Souar, Y., Mahi, K., \& Ameur, I. 2015. The Impact of Marketing Mix Ele-ments on Customer Loyalty for an Algerian Telecommunication Com-pany. Expert Journal of Marketing, $3(1), 1-10$. 